\title{
Quantitative Analysis of Heavy Metals and Organic Compounds in Soil from Deir Kanoun Ras El Ain Dump, Lebanon
}

\author{
Jamilah Borjac (D), ${ }^{1}$ Manal El Joumaa, ${ }^{1}$ Lobna Youssef, ${ }^{2}$ Rawan Kawach, ${ }^{1}$ \\ and Diane A. Blake ${ }^{3}$ \\ ${ }^{1}$ Department of Biological Sciences, Beirut Arab University, Debbieh, Lebanon \\ ${ }^{2}$ Department of Chemistry, Beirut Arab University, Debbieh, Lebanon \\ ${ }^{3}$ Department of Biochemistry and Molecular Biology, Tulane University School of Medicine, New Orleans, LA, USA \\ Correspondence should be addressed to Jamilah Borjac; j.borjac@bau.edu.lb
}

Received 14 April 2019; Revised 18 July 2019; Accepted 4 March 2020; Published 26 May 2020

Academic Editor: Christophe Waterlot; christophe.waterlot@isa-lille.fr

Copyright ( 92020 Jamilah Borjac et al. This is an open access article distributed under the Creative Commons Attribution License, which permits unrestricted use, distribution, and reproduction in any medium, provided the original work is properly cited.

Recently, there has been a worldwide concern regarding soil contamination by heavy metals and organic compounds, especially in the developing countries including Lebanon that has suffered from solid waste mismanagement for decades. Deir Kanoun Ras El Ain is a village in southern Lebanon that possesses one of the country's worst dumps, and its leachates influx into a running canal that irrigates surrounding agricultural lands. The aim of this study was to determine the levels of some toxic heavy metals and organic compounds in different soil samples collected from the dump and along the canal during winter and summer seasons. Six research sites (four from the dump and two along the canal) were selected, and the soil samples for analysis were collected from a depth of around $10 \mathrm{~cm}$. Heavy metals (lead, cadmium, arsenic, and mercury) and organic compounds (phthalates, bisphenol A, and polyaromatic hydrocarbons) content were determined using atomic absorption and high pressure liquid chromatography, respectively. The conducted research confirmed high levels of contamination in the collected soil samples by both heavy metals and organic compounds. The present study provided evidence that different sampling sites accumulated heavy metals at concentrations that exceeded the average maximum permissible levels for sewage sludge and agricultural land. These findings suggest the need for mitigation measures by the Lebanese authorities and new waste management programs to resolve the problems associated with uncontrolled dumping of solid wastes in Lebanon.

\section{Introduction}

Recently, environmental contamination by high levels of heavy metals and organic compounds has raised the global public health concerns especially in the developing countries [1]. The major toxic heavy metals that lead to soil pollution are copper $(\mathrm{Cu})$, zinc $(\mathrm{Zn})$, cadmium $(\mathrm{Cd})$, lead $(\mathrm{Pb})$, arsenic (As), and mercury $(\mathrm{Hg})[2,3]$. Unlike organic pollutants, which are ultimately degraded to carbon dioxide and water, heavy metals, once discharged into the environment, are difficult to remove. These metals bind to soils and sediments and persist in the environment until mobilized by changes in weather patterns, hydrogeology, and/or the overlying vegetation [4]. Besides, contaminated soils appear to act as a sink for organic compounds such as phthalates, bisphenols, and polycyclic aromatic hydrocarbons (PAHs) which originate from the dumping/burning of industrial, household, electronic, plastic, and medical wastes [5]. In the soil, these organic compounds have low mobility, high durability, and high affinity to soil organic matter [6]. It has been reported as well that, at dumpsites where solid wastes are burned, contamination by heavy metals is often accompanied by contamination by organic compounds $[7,8]$.

In addition, soil contamination by heavy metals and organic compounds may affect water resources and agricultural areas where the soil-crop system plays a chief role in the exposure of humans to contaminants $[9,10]$. Humans may be exposed to soil contaminants through the food chain where consumption of crops grown in contaminated soils results in tissue accumulation and significant toxicity and illness when reaching critical values $[11,12]$. For example, chronic exposure to high levels of heavy metals has been 
associated with higher risks of bladder, kidney, liver, lung, and skin cancer [13]. More recently, toxic metal exposure has also been associated with an increased risk of cardiovascular disease [14]. Moreover, organic compounds, especially $\mathrm{PAHs}$, have been shown to exert carcinogenic, mutagenic, immunotoxic, and endocrine disrupting effects [15].

Lebanon has suffered from solid waste mismanagement for decades [16]. It lacks solid waste management plans, which resulted in random disposal, dumping, and open burning of wastes across the country [17]. Hundreds of landfills exist across the entire country and the leachates from these landfills influx into the soil and water resources [18]. The lax environmental policies in Lebanon resulted in exacerbated waste problems and detrimental effects on the health of residents [19]. Deir Kanoun Ras El Ain is one of a number of Lebanese villages where solid waste had been mismanaged for many years. It harbors a dump that contains medical, industrial, and household wastes, and its leachates influx into a running canal that irrigates surrounding agricultural lands [20]. The present study was conducted to assess the levels of different heavy metals and organic compounds in soil samples collected from the Deir Kanoun dump and canal at different sites, and during winter and summer seasons of 2017.

\section{Materials and Methods}

2.1. Site and Sample Collection. Samples were collected in triplicate during winter and summer seasons of 2017. Sampling sites included two along the canal and four surrounding the dump as presented in Table 1 . The soil samples were collected from topsoil at a depth of $0-10 \mathrm{~cm}$ and stored in sterile bags. The soil samples were air-dried at room temperature prior to the analysis of heavy metals, phthalates, bisphenol $\mathrm{A}$, and PAHs.

2.2. Heavy Metals Analysis. The concentrations of heavy metals such as lead, cadmium, arsenic, and mercury $(\mathrm{Pb}, \mathrm{Cd}$, As, and $\mathrm{Hg}$ ) were assessed in soil samples using atomic absorption spectrophotometer (Bioteckno, Model: GF95Z, UK). Analysis was performed at the Lebanese Agricultural Research Institute (LARI) in Lebanon. Details of the analysis procedure are available in Supplemental Materials.

2.3. Organic Compounds Extraction and Analysis. The methods for phthalates and bisphenol A extraction and fractionation were carried out according to those described by Fromme et al. [21]. Methods for polycyclic aromatic hydrocarbon extraction and fractionation were as described by Pule et al. [22]. Details are available in Supplemental Materials.

\section{Results}

3.1. Heavy Metals. The concentrations of heavy metals assessed in soil samples collected during summer season are presented in Table 2, and the soil quality standards used to
TABle 1: Sampling sites from Deir Kanoun dump and canal.

Site Location details

(i) Deir Kanoun canal

C1 (ii) Latitude (N): $33^{\circ} 13^{\prime} 43.77^{\prime \prime}$; longitude (E): $35^{\circ} 15^{\prime}$ $48.061^{\prime \prime}$

(i) Klayleh

C2 (ii) Latitude (N): $33^{\circ} 28^{\prime} 48.989^{\prime \prime}$; longitude (E): $35^{\circ} 20^{\prime}$ 20.399"

(i) Dump contact with $\mathrm{C} 1$

D1 (ii) Latitude (N): $33^{\circ} 13^{\prime} 43.77^{\prime \prime}$; longitude (E): $35^{\circ} 15^{\prime}$ 48.061"

(i) Dump $\sim 90^{\circ}$ to $\mathrm{C} 1$

D2 (ii) Latitude (N): $33^{\circ} 11^{\prime} 36.596^{\prime \prime}$; longitude (E): $35^{\circ} 13^{\prime}$ 27.829"

(i) Dump $\sim 180^{\circ}$ to $\mathrm{C} 1$

D3 (ii) Latitude (N): $33^{\circ} 13^{\prime} 122.609^{\prime \prime}$; longitude (E): $35^{\circ} 12^{\prime}$ $57.16^{\prime \prime}$

(i) Dump $\sim 220^{\circ}$ to $\mathrm{C} 1$

D4 (ii) Latitude (N): $33^{\circ} 13^{\prime} 43.453^{\prime \prime}$; longitude (E): $35^{\circ} 13^{\prime}$ $33.628^{\prime \prime}$

evaluate the levels of contamination are presented in Tables 3 and 4 . The variation in heavy metal concentrations in the soils at the studied sites is shown graphically in Figure 1.

$\mathrm{Pb}, \mathrm{Cd}, \mathrm{As}$, and $\mathrm{Hg}$ were abundant in all of the collected samples from dump and canal, where their concentrations ranged $504.3-1365 \mathrm{mg} / \mathrm{kg}, 77-131.1 \mathrm{mg} / \mathrm{kg}, 51-603.3 \mathrm{mg} / \mathrm{kg}$, and $0.16-6.48 \mathrm{mg} / \mathrm{kg}$, respectively. $\mathrm{Pb}$, $\mathrm{As}$, and $\mathrm{Hg}$ concentrations were the highest in soil samples collected from $\mathrm{C} 1$ site. Concerning samples collected around the dump, D4 site contained the highest concentrations of $\mathrm{Pb}(1306.07 \mathrm{mg} /$ $\mathrm{kg}$ ), while $\mathrm{Cd}$ and $\mathrm{Hg}$ were at the highest levels at D1 site (131.1 mg/kg and $3.58 \mathrm{mg} / \mathrm{kg}$, resp.). As was highly abundant in soil samples collected from D2 $(471.97 \mathrm{mg} / \mathrm{kg})$ and D3 $(521.7 \mathrm{mg} / \mathrm{kg})$ sites.

While absolute values of heavy metal contamination are important, especially during remediation efforts, these values do not take into account the relative toxicity of the individual metals present at each site. These relative toxicities are considered in the determination of the maximum permission limits (MPL) set by various governmental regulatory agencies. The maximal permissible levels for $\mathrm{Pb}, \mathrm{Cd}$, As, and $\mathrm{Hg}$ in sewage sludge are shown in Table 3. These MPLs are designed to restrict the use of heavily contaminated sewage sludge as agricultural fertilizer [32]. Since much of the land immediately adjoining this dump and canal is under cultivation (see Figure 2), we also report the MPL for heavy metals in agricultural soil in Table 4.

Comparison of the levels of heavy metals to the sewage sludge MPLs promulgated by several countries showed that $\mathrm{Pb}$ levels at $\mathrm{D} 3, \mathrm{D} 4$, and $\mathrm{C} 1$ sites surpassed the quality standards of EEC, France, US EPA, and CCME. In addition, the levels of $\mathrm{Cd}$ at all sites except $\mathrm{D} 4$ and $\mathrm{C} 1$ surpassed the sewage sludge MPLs of EEC, France, US EPA, and CCME. The D4 and C1 sites had Cd levels that fell below the MPLs promulgated by the US EPA; however, these Cd levels exceeded the Cd MPLS set by the European Union, Canada, and France. The levels of As at all sites except D1 highly exceeded the US EPA and CCME sewage sludge standards. 
TABLE 2: Average concentrations $(n=3)$ of heavy metals in soil collected from Deir Kanoun dump and canal. Contaminant concentrations of all metals are expressed in $\mathrm{mg} / \mathrm{kg}$.

\begin{tabular}{|c|c|c|c|c|c|c|}
\hline \multirow{2}{*}{ Heavy metal } & \multicolumn{6}{|c|}{ Sample site } \\
\hline & $\mathrm{D} 1$ & $\mathrm{D} 2$ & D3 & $\mathrm{D} 4$ & $\mathrm{C} 1$ & $\mathrm{C} 2$ \\
\hline $\mathrm{Pb}$ & $504.3 \pm 73.02$ & $622.1 \pm 82.98$ & $1206.1 \pm 80.35$ & $1306.1 \pm 12.62$ & $1365 \pm 31.5$ & $728.4 \pm 83.68$ \\
\hline $\mathrm{Cd}$ & $131.1 \pm 32.21$ & $118.7 \pm 15.03$ & $117 \pm 24.44$ & $77 \pm 27.22$ & $78 \pm 9.46$ & $104.4 \pm 5.5$ \\
\hline As & $51 \pm 15.54$ & $471.97 \pm 77.42$ & $521.7 \pm 74.68$ & $95.87 \pm 15.75$ & $603.3 \pm 91.08$ & $281.6 \pm 86.81$ \\
\hline $\mathrm{Hg}$ & $3.587 \pm 1.27$ & $0.459 \pm 0.156$ & $2.39 \pm 0.416$ & $0.16 \pm 0.044$ & $6.48 \pm 0.761$ & $0.38 \pm 0.073$ \\
\hline
\end{tabular}

TABLE 3: Guidelines for the maximum permissible limit (MPL) values of selected heavy metals in sewage sludge used as agricultural fertilizer.

\begin{tabular}{lccccc}
\hline Heavy metal & US EPA $^{\text {a }} \mathrm{mg} / \mathrm{kg}$ & CCME $^{\mathrm{b}} \mathrm{mg} / \mathrm{kg}$ & EEC $^{\mathrm{c}} \mathrm{mg} / \mathrm{kg}$ & France $^{\mathrm{d}} \mathrm{mg} / \mathrm{kg}$ & Average* value $\mathrm{mg} / \mathrm{kg}$ \\
\hline $\mathrm{Pb}$ & 840 & 600 & $750-1200$ & 800 & 804 \\
$\mathrm{Cd}$ & 85 & 22 & $20-40$ & 20 & 39.25 \\
$\mathrm{As}$ & 75 & $40-75$ & - & - & 66.25 \\
$\mathrm{Hg}$ & 17 & 24 & $16-25$ & 10 & 17.88 \\
\hline
\end{tabular}

${ }^{a}$ United States Environmental Protection Agency [23]. ${ }^{\mathrm{b}}$ Canadian Council of Ministers of the Environment [24]. ${ }^{\mathrm{c}}$ European Economic Community/European Union [25]. ${ }^{\mathrm{d}}$ Data for France [25]. *Where a range is reported, the average value was calculated from the midpoint.

TABLE 4: Guidelines for the maximum permissible limit (MPL) values of selected heavy metals in agricultural soil.

\begin{tabular}{|c|c|c|c|c|c|c|c|c|c|}
\hline Metal & $\begin{array}{c}\mathrm{FAO} / \mathrm{WHO}^{\mathrm{a}} \\
\mathrm{mg} / \mathrm{kg}\end{array}$ & $\begin{array}{c}\mathrm{EC}^{\mathrm{b}} \\
\mathrm{mg} / \mathrm{kg}\end{array}$ & $\begin{array}{c}\mathrm{US}^{\mathrm{c}} \\
\mathrm{mg} / \mathrm{kg}\end{array}$ & $\begin{array}{c}\text { France }^{\mathrm{d}} \\
\mathrm{mg} / \mathrm{kg}\end{array}$ & $\begin{array}{l}\text { Germany }^{\mathrm{d}} \\
\mathrm{mg} / \mathrm{kg}\end{array}$ & $\begin{array}{l}\text { Austria }^{\mathrm{d}} \\
\mathrm{mg} / \mathrm{kg}\end{array}$ & $\begin{array}{c}\text { SEPA China } \\
\text { (Grade III) } \mathrm{mg} / \mathrm{kg}\end{array}$ & $\begin{array}{c}\text { Arab-German } \\
\text { Coop Project }^{\mathrm{f}} \\
\mathrm{mg} / \mathrm{kg}\end{array}$ & $\begin{array}{c}\text { Average* } \\
\mathrm{mg} / \mathrm{kg}\end{array}$ \\
\hline $\mathrm{Pb}$ & $90-400$ & $50-300$ & $50-300$ & $70-150$ & 100 & 100 & 500 & 100 & 166.25 \\
\hline $\mathrm{Cd}$ & & 1-3 & 1.6 & $1-3$ & $1.5-3$ & 5 & 1 & 1 & 2.12 \\
\hline As & - & 20 & 14 & 30 & 50 & 50 & - & - & 32.8 \\
\hline $\mathrm{Hg}$ & 1 & 1 & 0.5 & 1 & 2 & 5 & 1.5 & - & 1.71 \\
\hline
\end{tabular}

${ }^{\mathrm{a}}$ Food and Agriculture Organization of the United Nations and the World Health Organization [26]. ${ }^{\mathrm{b}}$ European Council/Union [27]. ${ }^{\mathrm{C}}$ United States [28]. ${ }^{\mathrm{d}}$ Data for France, Germany and Austria [29]. ${ }^{\mathrm{e}}$ State Environmental Protection Administration of China [30]. ${ }^{\mathrm{f}}$ Arab-German Cooperation project $1997-2003$ [31]. ${ }^{*}$ Where a range is reported, the average value was calculated from the midpoint.

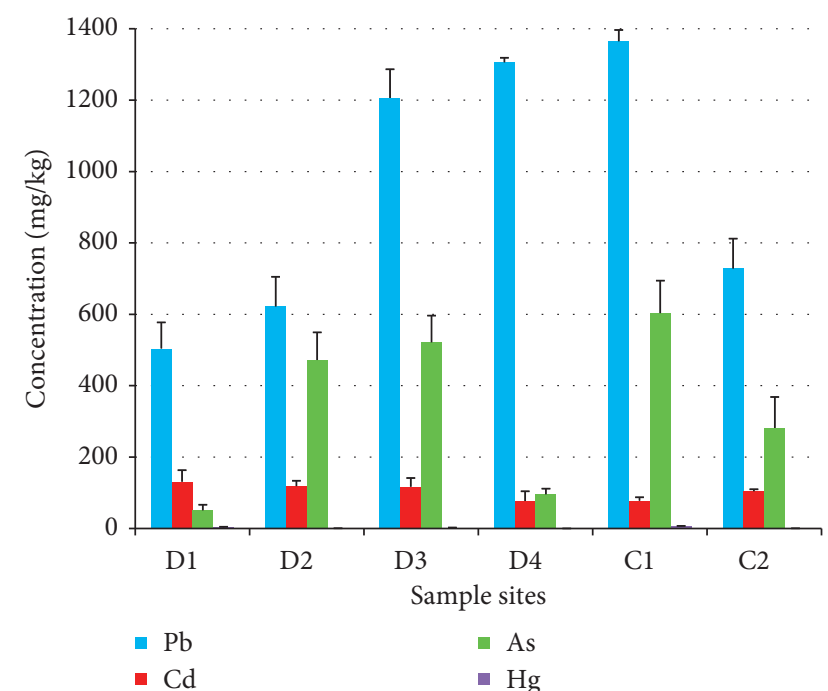

Figure 1: Distribution of heavy metals among different sampling sites.

Only three EU member states (Bulgaria, Czech Republic, and Denmark) currently regulate As in sewage sludge, with an MPL of $25-30 \mathrm{mg} / \mathrm{kg}$ [32]; the levels of As at all sites exceeded this value. Levels of $\mathrm{Hg}$ were below the MPL values of all sewage sludge guidelines.
An average MPL value for each metal was calculated (Table 1 supplementary material) and used to calculate the 'fold above the average maximum permissible level' for each metal at each site, as shown in Figure 3. This analysis provides insight into the relative toxicity of the tested metals at each site. Results show that As levels had the highest fold above average MPL at most sites, followed by $\mathrm{Cd}$ and $\mathrm{Pb}$. Samples from site $\mathrm{C} 1$ were the most concerning, with the following values: As, 9.5-fold; $\mathrm{Cd}, 2$-fold; and $\mathrm{Pb}, 1.63$-fold above the maximum average permissible level of heavy metals.

Soil samples collected were also from surrounding agricultural lands apart the sludge soil. Thus, we compared the levels of the heavy metals analyzed in these samples to the maximum permissible limits of agricultural soil, as set by the guidelines shown in Table 4. These comparisons showed that the concentrations of $\mathrm{Pb}, \mathrm{Cd}$, and $\mathrm{As}$ in all soil samples surpassed the quality standards of FAO/WHO, European council/union, United States, France, Germany, Austria, China, and Arab-German Cooperation project 1997-2003. The level of analyzed Hg was above the MPLs only at D1 and D3 site. Note that site $\mathrm{C} 1$, which has relatively high levels of heavy metals and is directly in contact with the dump leachate, is not used for planting purposes.

To provide a clearer indication of which of the metals may pose the greatest risks to residents who may consume food grown in the agricultural land surrounding the studied 

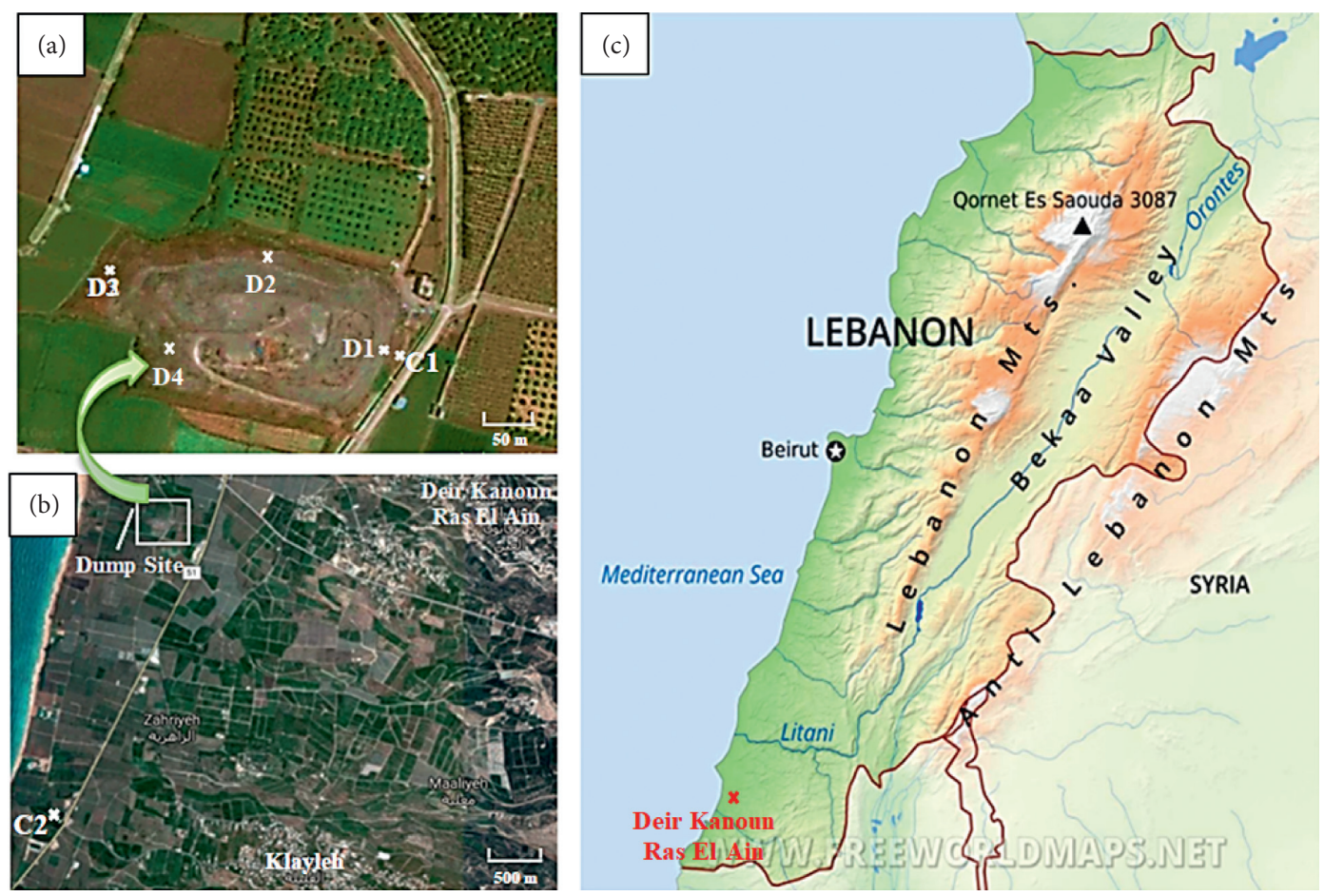

Figure 2: (a, b) The study area showing the dump and canal sites (D1, D2, D3, D4, C1, and C2). (c) Map of Lebanon showing Deir Kanoun Ras El Ain village.

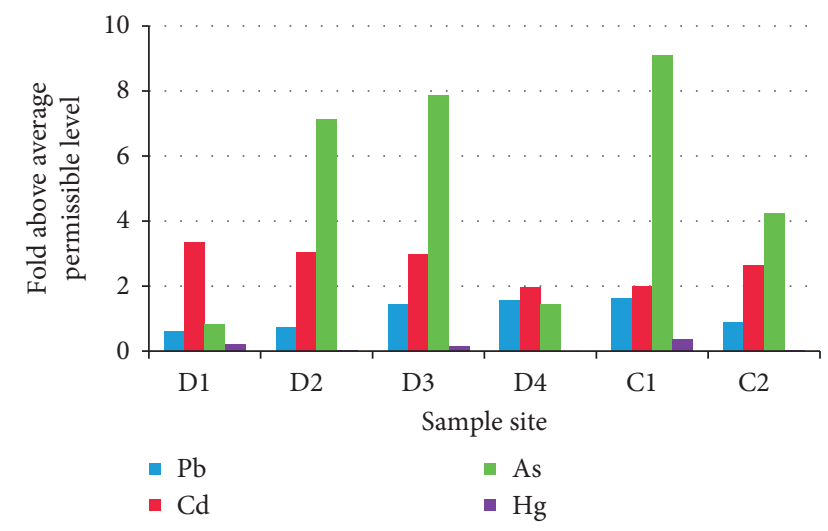

FIGURE 3: Relative toxic effects of heavy metals at different sampling sites, expressed as fold above average permissible level in sewage sludge.

dump area, the fold above the agricultural MPL for each metal at each site was also calculated and presented in Figure 4. Results showed that Cd levels highly exceeded the average MPL, followed by $\mathrm{As}$ and $\mathrm{Pb}$. The highest fold above MPL for Cd was obtained at site D1 (62 -fold), whereas the highest fold above MPL for $\mathrm{As}, \mathrm{Pb}$, and $\mathrm{Hg}$ was obtained at site C1 (18.4-, 8.2-, and 3.8-fold, resp.).

3.2. Organic Compounds. The levels of organic compounds expected at dumpsites (plastic residues and products of incomplete combustion) were also assessed in soil samples collected from the dump and canal sites during two seasons. These data are presented in Table 5.

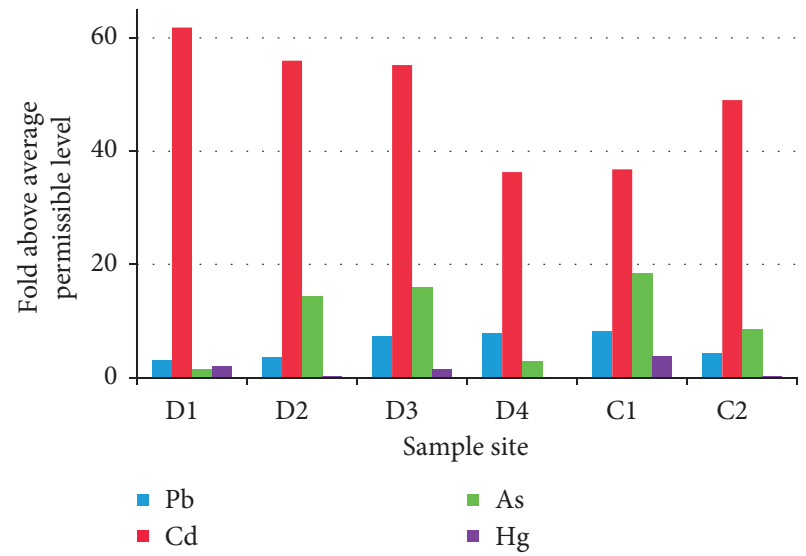

FIgURE 4: The distribution of fold above average permissible level of different heavy metals for agricultural soil among different sample sites.

As seen in Table 5, winter collections (W) showed that samples collected from the D1 site contained the highest concentrations of di-n-butyl-phalate (DBH. $6.25 \mathrm{mg} / \mathrm{kg}$ ) and bis(2-ethylhexyl) phthalate (DEHP, $12.59 \mathrm{mg} / \mathrm{kg}$ ) and also of bisphenol A that leach from the food storage containers, bottle tops, and the coatings on medical devices (BPA, $1.454 \mathrm{mg} / \mathrm{kg}$ ). The concentrations of DEHP and BPA showed a decreasing pattern from the D1 to the D4 sites. Benzo $\alpha$-pyrene (BAP), a carcinogenic polycyclic hydrocarbon produced during incomplete combustion, was detected only in samples collected from the D3 $(0.022 \mathrm{mg} / \mathrm{kg})$ and D4 $(0.012 \mathrm{mg} / \mathrm{kg})$ sites. Samples collected from C2 site showed detectable concentrations of BAP $(0.075 \mathrm{mg} / \mathrm{kg})$. Summer 


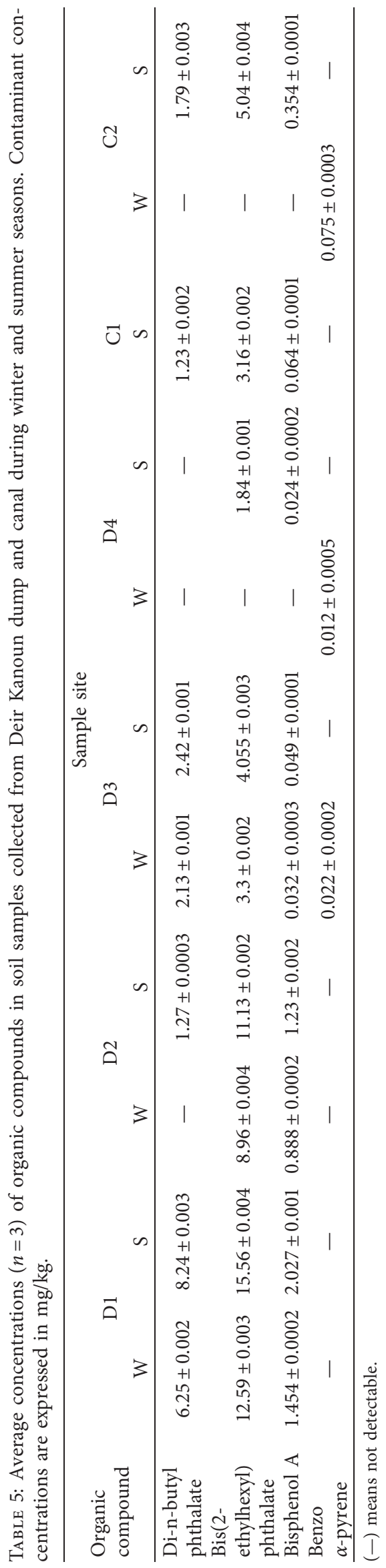


collections (S) revealed a similar abundance of residues from plastic waste among different sites. DBH, DEHP, and BPA concentrations showed decreasing patterns where the highest concentrations were in samples collected from D1 site $(8.24,15.56$, and $2.027 \mathrm{mg} / \mathrm{kg}$, respectively) while the lowest concentrations were in samples collected from D4 site (DBH was undetectable; DEHP and BPA were 1.84 and $0.024 \mathrm{mg} / \mathrm{kg}$, respectively). Regarding soil samples collected near the canal, $\mathrm{DBH}$ concentrations in samples collected from C2 site $(1.79 \mathrm{mg} / \mathrm{kg})$ were higher than the ones collected from $\mathrm{C} 1$ site $(1.23 \mathrm{mg} / \mathrm{kg})$. Likewise, DEHP and BPA concentrations in $\mathrm{C} 2$ site $(5.04$ and $0.354 \mathrm{mg} / \mathrm{kg}$, respectively) were higher than those from $\mathrm{C} 1$ site (3.16 and $0.064 \mathrm{mg} / \mathrm{kg}$ ). Benzo $\alpha$-pyrene was undetectable in all samples collected during the summer season.

\section{Discussion}

The lack of waste management policies in Lebanon has led to uncontrolled dumping of both household and hazardous solid wastes [16-19]. Deir Kanoun Ras El Ain is one of the villages that suffered from the presence of a dump that includes medical, industrial, and household wastes. Leachates from this dump flow into a canal that circles the dumpsite. These wastes and their leachates are major sources of heavy metals and organic compounds that are known to cause adverse health and environmental hazards [20].

Regarding heavy metals, our findings indicate that $\mathrm{Pb}$, $\mathrm{Cd}$, and As were the most serious metal pollutants in soil samples collected from Deir Kanoun dump and canal. Upon comparing our data to previously published research studies, it was noted that our findings are similar to those obtained by Tang et al. [33] where there were high levels of $\mathrm{Pb}$ and $\mathrm{Hg}$ in soil samples collected from a dumpsite in China (81.3-2374.1 mg/kg and 0.2-3.2 mg/kg, respectively). Similarly, the levels of $\mathrm{Pb}$ and $\mathrm{Hg}$ in our study are similar to those obtained in soil samples collected from a dumpsite in Croatia (605-968 mg/kg and $0.73-1.51 \mathrm{mg} / \mathrm{kg}$, resp.) [34]. However, our obtained levels of $\mathrm{Cd}$ are higher than those of China's dumps (0.6-12.5 mg/kg) [33], Nigeria $(17.00-47.06 \mathrm{mg} / \mathrm{kg})$ [35], and Croatia (70-72 mg/kg) [34]. Likewise, $\mathrm{Pb}$ levels in this study are higher than those collected from dumps in Nigeria (63.58-418.58 mg/kg) [35] and in Sweden (254-895 mg/kg) [36].

Additionally, the levels of $\mathrm{Pb}, \mathrm{Cd}$, and As exceeded the sewage sludge maximum permissible limits (MPL) of several quality standards. Fold above average MPL for each metal at each site showed that As levels had the highest fold above average MPL followed by $\mathrm{Cd}$ and $\mathrm{Pb}$. Comparing our results to the MPL of heavy metals in agricultural soil set by different guidelines showed that the concentrations of $\mathrm{Pb}, \mathrm{Cd}$, and As in all soil samples greatly surpassed the quality standards of several agencies. It should be noted that the dump area in Deir Kanoun Ras El Ain is surrounded by agricultural lands, and the canal from which samples were collected irrigates these lands. The fact that $\mathrm{Cd}$ and As greatly exceed the MPLs for both sewage sludge and agricultural soil indicates that these two metals may pose a risk to residents who live near the dumpsite and consume crops grown in contaminated agricultural lands. In fact, high levels of $\mathrm{Pb}, \mathrm{Cd}$, and As have been shown to exert damaging effects and serious disorders in living organisms [37, 38]. For example, short term exposure to $\mathrm{Pb}$ at high concentrations often causes vomiting, fatigue, diarrhea, convulsions, coma, or death [39], and even low concentrations of this metal are dangerous to young children because it can affect their nervous systems [40]. Inhabitants exposed to Cd may develop damage in their lungs, bones, and kidneys [41]. In humans, even low levels of As are considered toxic as they may cause adverse damaging effects on the brain, liver, kidney, stomach, and intestines [42, 43].

Moreover, the findings reported herein are of serious concern since Cd has been widely associated with decreased bone mineral density which subsequently leads to increased risk of bone fracture in both experimental models and populations-based studies $[44,45]$. This fact led us to investigate the prevalence of bone fracture among Lebanese and Syrian refuges living in three villages surrounding the dump region. Unpublished results of data collected from residents of the region under study revealed that $27.4 \%$ of participants suffered bone fractures. Such findings are consistent with previous studies that proved the associations between low-level $\mathrm{Cd}$ exposure and (1) decreased bone mineral density and (2) increased risk of bone fractures in elderly men [46-50].

In addition to heavy metals, we were also able to detect the presence of phthalates (DBP and DEHP), bisphenol A, and benzo $(\alpha)$ pyrene in most of the collected soil samples. Regarding phthalates, a study by Zorníková \& Hřivna in Czech Republic showed that agricultural soil samples contained $0.28-1.59 \mathrm{mg} / \mathrm{kg}$ di-n-butyl phthalate (DEHP) and $0.03-0.73 \mathrm{mg} / \mathrm{kg}$ bis(2-ethylhexyl) phthalate (DBP) which are lower than the findings of the present study [51]. In addition, a study by Vikelsøe et al. in Denmark revealed that the concentrations of di-(n-butyl)-phthalate (DBP) and di(2-ethylhexyl)-phthalate (DEHP) in sewage sludge soil samples were $439-453 \mu \mathrm{g} / \mathrm{kg}$ and $1110-1900 \mu \mathrm{g} / \mathrm{kg}$, respectively [52]. On the other hand, the concentrations of DBP and DEHP in agricultural soil samples were $0.5-1.1 \mu \mathrm{g} / \mathrm{kg}$ and $12-40 \mu \mathrm{g} / \mathrm{kg}$, respectively. According to the Danish guidelines, the levels of DBP and DEHP should be limited to $0.01-0.98 \mu \mathrm{g} / \mathrm{kg}$ in fertilized soils and $1450-2430 \mu \mathrm{g} / \mathrm{kg}$ in sewage sludge [53]. Most of our findings exceed the limits set by the Danish guidelines suggesting risks for organisms and humans especially that different studies documented the ability of DBP and DEHP to act as endocrine disruptors [54-56].

Besides phthalates, bishenol A (BPA) is an important organic compound that acts as an endocrine disruptor, mainly as an estrogen, and it is widely used in the industrial manufacture of plastics [57]. Due to the substantial widespread of the use and involvement of BPA in soil amendments, there is a growing concern about its presence and possible toxicity in soils especially those cultivated with crops [58]. Our findings showed that the collected soil samples contained a range of $0.024-2 \mathrm{mg} / \mathrm{kg}$ of BPA which is greater than that found in sludge from the Midwest USA $(4.6 \mathrm{mg} / \mathrm{kg}$; [59]) and Canada (36.7 mg/kg; [60]). However, our findings 
are similar to those reported in several countries, such as Greece $(0.62 \mathrm{mg} / \mathrm{kg}$; [61]), Spain $(0.005-0.68 \mathrm{mg} / \mathrm{kg}$; [62]), South California (0.066-0.217 ng g-1; [63]); and Germany $(0.004-1.363 \mathrm{mg} / \mathrm{kg} ;[21])$. On the other hand, they are higher than those reported in Gran Canaria, Spain (0.0014-0.055 mg/kg; [64]), and Ontario, Canada ( $\sim 0.004 \mathrm{mg} /$ $\mathrm{kg}$; [65]). Thus, our data imply that the levels of BPA in the samples collected in the current study are of a moderate level and within previously reported ranges.

Regarding PAHs, our study focused on benzo $(\alpha)$ pyrene which is one of the highly toxic PAHs in the soil-crop system [66]. It is released to the environment as a result of combustion and can easily accumulate in organisms exposed to it causing potential carcinogenic and mutagenic effects $[67,68]$. Our results revealed the presence of benzo $(\alpha)$ pyrene in three sites only at concentrations of $0.012-0.075 \mathrm{mg} / \mathrm{kg}$, which are similar to those reported in soil samples from regions in Poland $(0.05-0.19 \mathrm{mg} / \mathrm{kg}$; [69]), Spain $(0.018-0.1 \mathrm{mg} / \mathrm{kg}$; [70]), South Korea (0.0124-0.0211 mg/kg; [71]), and Canada $(\sim 0.031 \mathrm{mg} / \mathrm{kg}$; [72]). Also, our findings are similar to those obtained in soil samples collected from an E-waste dumpsite in China (0.0011-0.0256 mg/kg; [33]).

Finally, it is crucial to provide a brief comparison of pollution between the different sites of soil collection. Among all the studied sites, sites C1, D4, and D3 were the most heavily contaminated with heavy metals, while site D1 had the highest levels of organic compounds. There are several factors that lead to the different levels and distribution of heavy metals and organic compounds, such as the type of dumped waste at each site, soil properties, soil organic matter (SOM), distance to the sources of contamination, use of lands, type of grown crops, and dry or wet depositions which may explain why our summer collections had higher levels of organic compounds than winter collections $[2,3]$. Moreover, site C2, which is farther from the dump, had higher levels of organic compounds than site C1. This observation could be attributed to the litter of consumer waste products and plastics at site $\mathrm{C} 2$ where refugee families live in camps with poor hygiene conditions and with little or no consideration to health protection. The high levels of heavy metals and organic compounds at this particular site imply that the individuals living in that region are at high health risks, knowing that the dump leachates influx to the canal used for irrigating the surrounding agricultural lands and drinking. However, data regarding human exposure are still limited and further studies are required to assess the impacts on human health.

It should be taken into consideration that the toxicological effects of such compounds depend on their bioavailability, metabolism, and excretion into organisms and humans. Thus, the current results suggest further investigation of the levels of heavy metals and organic compounds in crops grown in agricultural lands near the dump and irrigated from the canal. Furthermore, serious actions and mitigation measures must be taken by the Lebanese authorities to solve the current environmental disaster as well as other similar dumps. Additionally, it is hoped that these findings lead to a greater awareness of the hazardous consequences of unregulated waste dumping.

\section{Conclusion}

The results of the current study show that soil samples collected from Deir Kanoun Ras El Ein dump and canal were heavily contaminated with heavy metals. The presence of organic compounds including phthalates, bisphenol, and PAHs was also noted. The concentrations of heavy metals highly exceeded the permissible limits recommended by different agencies. The presence of heavy metals and organic compounds in the irrigation canal may also affect agricultural lands that are irrigated by canal's water and, ultimately, the health of inhabitants who consume the crops grown in these contaminated soils. More studies are clearly needed to determine the extent of heavy metal contamination at various distances from the dump's site and in the crops grown in fields both adjacent to and more distant from this dump. Since both the heavy metals and organic pollutants are a result of the uncontrolled dumping of solid waste at this site, stricter environmental policies regarding waste management should be implemented by the Lebanese authorities and guidance should be given to local inhabitants about healthy management practices regarding information pertinent to their health status.

\section{Data Availability}

All data in this study are included in the figures, tables, and supplementary data.

\section{Conflicts of Interest}

The authors declare that they have no conflicts of interest.

\section{Acknowledgments}

This work was financially supported by the U.S National Academy of Science PEER Cycle 5 Program for Grant no. 556 and Grant Award Number AID-OAA-A-11-00012.

\section{Supplementary Materials}

It includes detailed methods to determine the heavy metals and organic compounds and our calculation of average minimum permissible levels of heavy metals and their relationships to levels in the soils analyzed in this study, as well as graphic of organic contaminant levels at test sites during winter and summer. (Supplementary Materials)

\section{References}

[1] H. Bradl, Sources and Origins of Heavy Metals Heavy Metals in the Environment: Origin, Interaction and Remediation, H. Bradl, Ed., vol. 6, Academic Press, London, UK, 2002.

[2] L. Järup, "Hazards of heavy metal contamination," British Medical Bulletin, vol. 68, no. 1, pp. 167-182, 2003.

[3] R. A. Wuana and F. E. Okieimen, "Heavy metals in contaminated soils: a review of sources, chemistry, risks and best available strategies for remediation," ISRN Ecology, vol. 2011, Article ID 5493270, 20 pages, 2011.

[4] R. R. Wijngaard, M. van der Perk, B. van der Grift, T. C. M. de Nijs, and M. F. P. Bierkens, "The impact of climate 
change on metal transport in a lowland catchment," Water, Air, \& Soil Pollution, vol. 228, p. 107, 2017.

[5] Y. Kalmykova, N. Moona, A.-M. Strömvall, and K. Björklund, "Sorption and degradation of petroleum hydrocarbons, polycyclic aromatic hydrocarbons, alkylphenols, bisphenol A and phthalates in landfill leachate using sand, activated carbon and peat filters," Water Research, vol. 56, pp. 246-257, 2014.

[6] J. Lasota and E. Błońska, "Polycyclic aromatic hydrocarbons content in contaminated forest soils with different humus types," Water, Air, \& Soil Pollution, vol. 229, no. 6, p. 204, 2018.

[7] A. A. Adeyi and P. Oyeleke, "Heavy metals and polycyclic aromatic hydrocarbons in soil from e-waste dumpsites in Lagos and Ibadan, Nigeria," Journal of Health and Pollution, vol. 7, no. 15, pp. 71-84, 2017.

[8] N. Peng, Y. Li, T. Liu, Q. Lang, C. Gai, and Z. Liu, "Polycyclic aromatic hydrocarbons and toxic heavy metals in municipal solid waste and corresponding hydrochars," Energy Fuels, vol. 31, pp. 1665-1671, 2017.

[9] J. J. Pignatello, B. G. Katz, and H. Li, "Sources, interactions, and ecological impacts of organic contaminants in water, soil, and sediment: an introduction to the special series," Journal of Environmental Quality, vol. 39, no. 4, pp. 1133-1138, 2010.

[10] K. S. Balkhair and M. A. Ashraf, "Microbial contamination of vegetable crop and soil profile in arid regions under controlled application of domestic wastewater," Saudi Journal of Biological Sciences, vol. 23, no. 1, pp. S83-S92, 2016.

[11] W.-X. Liu, L.-F. Shen, J.-W. Liu, Y.-W. Wang, and S.-R. Li, "Uptake of toxic heavy metals by rice (Oryza sativa L.) cultivated in the agricultural soil near Zhengzhou city, People's Republic of China," Bulletin of Environmental Contamination and Toxicology, vol. 79, no. 2, pp. 209-213, 2007.

[12] M. Jaishankar, T. Tseten, N. Anbalagan, B. B. Mathew, and K. N. Beeregowda, "Toxicity, mechanism and health effects of some heavy metals," Interdisciplinary Toxicology, vol. 7, no. 2, pp. 60-72, 2014.

[13] International Agency for Research on Cancer, Arsenic, Metals, Fibres and Dust IARC Monographs on the Evaluation of Carcinogenic Risks to Humans, vol. 100C, International Agency for Research on Cancer, Lyon, France.

[14] R. Chowdhury, A. Ramond, L. M O’Keeffe et al., "Environmental toxic metal contaminants and risk of cardiovascular disease: systematic review and meta-analysis," BMJ, vol. 362, Article ID k3310, 2018.

[15] K. Srogi, "Monitoring of environmental exposure to polycyclic aromatic hydrocarbons: a review," Environmental Chemistry Letters, vol. 5, no. 4, pp. 169-195, 2007.

[16] S. Atallah, Garbage Crisis: Setting The Record Straight, The Lebanese Center for Policy Studies, Beirut, Lebanon, 2015, https://www.lcps-lebanon.org/featuredArticle.php?id=48.

[17] Ministry of Environment, Country Report on the Solid Waste Management in Lebanon, Ministry of Environment, Beirut, Lebanon, 2014, http://www.moe.gov.lb.

[18] K. Shellito, The Economic Effect of Refugee Crises on Host Countries and Implication for the Lebanese Case, Penn Libraries, University of Pennsylvania, Philadelphia, PA, USA, 2016, https://repository.upenn.edu/cgi/viewcontent.cgi?article $=1022 \&$ context=joseph_wharton_scholars.

[19] Human Rights Watch, Lebanon: Waste Crisis Posing Health Risks, Human Rights Watch, Beirut, Lebanon, 2017, https:// www.hrw.org/news/2017/12/01/lebanon-waste-crisis-posinghealth-risks.
[20] Geoflint, 2017, Environmental and Social Impact Assessment Plot Number/765/Ain Baal, Tyre South Lebanon, http://www. cdr.gov.lb/stuy/EISAAinbaalFina.pdf.

[21] H. Fromme, T. Küchler, T. Otto, K. Pilz, J. Müller, and A. Wenzel, "Occurrence of phthalates and bisphenol A and F in the environment," Water Research, vol. 36, pp. 1429-1438, 2002.

[22] B. O. Pule, L. C. Mmualefe, and N. Torto, Analysis of Polycyclic Aromatic Hydrocarbons in Soil with Agilent Bond Elut HPLCFLD, Agilent Technologies, Santa Clara, CA, USA, 2012, https:// www.agilent.com/cs/library/applications/5990-5452EN.pdf.

[23] US Environmental Protection Agency (US EPA), Sewage Sludge (Biosolids), US Environmental Protection Agency (US EPA), Washington, DC, USA, 2018, http://water.epa.gov/ polwaste/wastewater/treatment/biosolids/index.cfm.

[24] Canadian Council of Ministers of the Environment (CCME), A Review of the Current Canadian Legislative Framework for Wastewater Biosolids, Canadian Council of Ministers of the Environment (CCME), Winnipeg, Canada, 2010, https://www. ccme.ca/files/Resources/waste/biosolids/pn_1446_biosolids_leg_ review_eng.pdf.

[25] V. Inglezakis, A. Zorpas, A. Karagiannidis, P. Samaras, I. Voukkali, and S. Sklari, "European Union legislation on sewage sludge management," Fresenius Environmental Bulletin, vol. 23, pp. 635-639, 2014.

[26] FAO/WHO, Codex Alimentarius Commission, WHO, Food additives and contaminants joint FAO/WHO food standards programme," pp. 1-289, Geneva, Switzerland, 2001, ALINORM01/12A.

[27] G. Tóth, T. Hermann, M. R. Da Silva, and L. Montanarella, "Heavy metals in agricultural soils of the European Union with implications for food safety," Environment International, vol. 88, pp. 299-309, 2016.

[28] Environmental Protection Agency (US EPA), “Supplemental guidance for developing soil screening levels for superfund sites," Office of Solid Waste and Emergency Response, Washington, DC, USA, 2002, http://www.epa.gov/superfund/ health/conmedia/soil/index.html.

[29] European Commission Director General Environment (ECDGE), Heavy Metals and Organic Compounds from Wastes Used as Organic Fertilizers Final Rep, WPA Consulting Engineers Inc., Bengaluru, Karnataka, 2010, http://ec.europa.eu/environment/waste/compost/pdf/hm_finalreport.pdf.

[30] State Environmental Protection Administration of China (SEPA), Environmental Quality Standards for Soils (GB156181995), State Environmental Protection Administration of China (SEPA), Beijing, China, 1995, http://www.sepa.gov.cn/ english/index.php3.

[31] BGR, ACSAD, CNRS-CRS 1997-2003 Arab German Technical Cooperation Project Management, Protection and Sustainable Use of Groundwater and Soil Resources in the Arab Region.

[32] H. Hudcova, J. Vymazal, and M. Rozkosny, "Present restrictions of sewage sludge applications in agriculture within the European Union," Soil and Water Research, vol. 14, pp. 104-120, 2018.

[33] X. Tang, C. Shen, D. Shi et al., "Heavy metal and persistent organic compound contamination in soil from Wenling: an emerging e-waste recycling city in Taizhou area, China," Journal of Hazardous Materials, vol. 173, no. 1-3, pp. 653-660, 2010.

[34] J. Hršak, A. Šišović, A. Škrbec, and K. Šega, "Seasonal differences in the levels of suspended particulate matter and 
heavy metals in the vicinity of a waste dump," Atmospheric Environment, vol. 35, pp. 3543-3546, 2001.

[35] A. A. Amusan, D. V. Ige, and R. Olawale, "Characteristics of soils and crops' uptake of metals in municipal waste dump sites in Nigeria," Journal of Human Ecology, vol. 17, no. 3, pp. 167-171, 2005.

[36] Z. Lin and R. B. Herbert Jr., "Heavy metal retention in secondary precipitates from a mine rock dump and underlying soil, Dalarna, Sweden," Environmental Geology, vol. 33, no. 1, pp. 1-12, 1997.

[37] C. M. A. Ademorati, Pollution by Heavy Metals Environmental Chemistry And Toxicology, Foludex Press, Ibadan, Nigeria, 1st edition, 1996.

[38] C. V. A. Duke and C. D. Williams, Soil Pollution Chemistry for Environment And Earth Sciences, CRC Press: Taylor and Francis Group, Boca Raton, FL, USA, 2008.

[39] L. Jarup, M. Berglund, C. G. Elinder, G. Nordberg, and M. Vahter, "Health effects of cadmium exposure-a review of the literature and a risk estimate," Scandinavian Journal of Work, Environment \& Health, vol. 24, pp. 1-51, 1998.

[40] E. E. Awokunmi, S. S. Asaolu, and K. O. Ipinmoroti, "Effects of leaching on heavy metals concentrations of soil in some dumpsites," African Journal of Environmental Science and Technology, vol. 4, pp. 495-499, 2010.

[41] The Centre for International Law, International Transport for Lead and Cadmium via Trade: An International Concern?, Vol. 8, Intergovernmental Forum on Chemical Safety, Budapest, Hungary, 2008.

[42] B. C. Gbaruko and O. V. Friday, "Bioaccumulation of heavy metals in some fauna and flora," International Journal of Environmental Science \& Technology, vol. 4, no. 2, pp. 197202, 2007.

[43] J. M. Gorell, B. A. Rybicki, C. Cole Johnson, and E. L. Peterson, "Occupational metal exposures and the risk of Parkinson's disease,” Neuroepidemiology, vol. 18, pp. 303-308, 1999.

[44] X. Cheng, Y. Niu, Q Ding et al., "Cadmium exposure and risk of any fracture: a PRISMA-compliant systematic review and meta-analysis," Medicine, vol. 95, Article ID e2932, 2016.

[45] M. M. Brzóska and J. Moniuszko-Jakoniuk, "Low-level exposure to cadmium during the lifetime increases the risk of osteoporosis and fractures of the lumbar spine in the elderly: studies on a rat model of human environmental exposure," Toxicological Sciences: An Official Journal of the Society of Toxicology, vol. 82, pp. 468-477, 2004.

[46] M. Wallin, L. Barregard, G. Sallsten et al., "Low-level cadmium exposure is associated with decreased bone mineral density and increased risk of incident fractures in elderly men: the MrOS Sweden study," Journal of Bone and Mineral Research, vol. 31, no. 4, pp. 732-741, 2016.

[47] G. F. Nordberg, "Historical perspectives on cadmium toxicology," Toxicology and Applied Pharmacology, vol. 238, no. 3, pp. 192-200, 2009.

[48] A. Engström, K. Michaëlsson, M. Vahter, B. Julin, A. Wolk, and A. Åkesson, "Associations between dietary cadmium exposure and bone mineral density and risk of osteoporosis and fractures among women," Bone, vol. 50, pp. 1372-1378, 2012.

[49] N. Kōji, Y. Yuichi, H Ryumon et al., “The relationship between itai-itai disease among inhabitants of the jinzu river basin and cadmium in rice," Toxicology Letters, vol. 17, pp. 263-266, 1983.

[50] K. Aoshima, "Itai-itaidisease: renal tubular osteomalacia induced by environmental exposure to cadmium-historical review and perspectives," Soil Science and Plant Nutrition, vol. 62, no. 4, pp. 319-326, 2016.

[51] G. Zorníková, A. Jarošová, and L. Hřivna, "Distribution of phthalic acid esters in agricultural plants and soil," Acta Universitatis Agriculturae et Silviculturae Mendelianae Brunensis, vol. 59, pp. 233-238, 2014.

[52] J. Vikelsøe, M. Thomsen, and L. Carlsen, "Phthalates and nonylphenols in profiles of differently dressed soils," Science of the Total Environment, vol. 296, pp. 105-116, 2002.

[53] J. Vikelsøe, M. Thomsen, E. Johansen, and L. Carlsen, Phthalates and Nonylphenols in Soil. A Field Study of Different Soil Profiles, Technical report no.268, p. 128, National Environmental Research Institute, Roskilde, Denmark, 1999.

[54] A. Arditsoglou and D. Voutsa, "Determination of phenolic and steroid endocrine disrupting compounds in environmental matrices," Environmental Science and Pollution Research, vol. 15, no. 3, pp. 228-236, 2008.

[55] J. Högberg, A. Hanberg, M. Berglund et al., "Phthalate diesters and their metabolites in human breast milk, blood or serum, and urine as biomarkers of exposure in vulnerable populations," Environmental Health Perspectives, vol. 116, no. 3, pp. 334-339, 2008.

[56] R. MaurÍcio, M. Diniz, M. Petrovic et al., "A characterization of selected endocrine disruptor compounds in a Portuguese wastewater treatment plant," Environmental Monitoring and Assessment, vol. 118, no. 1-3, pp. 75-87, 2006.

[57] D. Kim, J. I. Kwak, and Y. J. An, "Effects of bisphenol A in soil on growth, photosynthesis activity, and genistein levels in crop plants (Vigna radiata)," Chemosphere, vol. 209, pp. 875-882, 2018.

[58] Z. Zhang, M. Le Velly, S. M. Rhind et al., "A study on temporal trends and estimates of fate of Bisphenol A in agricultural soils after sewage sludge amendment," Science of The Total Environment, vol. 515-516, pp. 1-11, 2015.

[59] C. A. Kinney, E. T. Furlong, D. W. Kolpin et al., "Bioaccumulation of pharmaceuticals and other anthropogenic waste indicators in earthworms from agricultural soil amended with biosolid or swine manure," Environmental Science \& Technology, vol. 42, no. 6, pp. 1863-1870, 2008.

[60] H.-B. Lee and T. E. Peart, "Bisphenol a contamination in canadian municipal and industrial wastewater and sludge samples," Water Quality Research Journal, vol. 35, no. 2, pp. 283-298, 2000.

[61] G. Gatidou, N. S. Thomaidis, A. S. Stasinakis, and T. D. Lekkas, "Simultaneous determination of the endocrine disrupting compounds nonylphenol, nonylphenol ethoxylates, triclosan and bisphenol A in wastewater and sewage sludge by gas chromatography-mass spectrometry," Journal of Chromatography A, vol. 1138, no. 1-2, pp. 32-41, 2007.

[62] N. Dorival-García, A. Zafra-Gómez, A. Navalón, and J. L. Vílchez, "Improved sample treatment for the determination Bisphenol A and its chlorinated derivatives in sewage sludge samples by pressurized liquid extraction and liquid chromatography-tandem mass spectrometry," Talanta, vol. 101, pp. 1-10, 2012.

[63] Y. Yu and L. S. Wu, "Analysis of endocrine disrupting compounds, pharmaceuticals and personal care products in sewage sludge by gas chromatography-mass spectrometry," Talanta, vol. 89, pp. 258-263, 2012.

[64] T. Vga-Morales, Z. Sosa-Ferrera, and J. J. Santana-Rodríguez, "Determination of various estradiol mimicking-compounds in sewage sludge by the combination of microwave assisted extraction and LC-MS/MS," Talanta, vol. 85, pp. 1825-1834, 2011. 
[65] S. Chu, G. D. Haffner, and R. J. Letcher, "Simultaneous determination of tetrabromobisphenol A, tetrachlorobisphenol $\mathrm{A}$, bisphenol $\mathrm{A}$ and other halogenated analogues in sediment and sludge by high performance liquid chromatographyelectrospray tandem mass spectrometry," Journal of Chromatography A, vol. 1097, no. 1-2, pp. 25-32, 2005.

[66] E. Manoli, A. Kouras, O. Karagkiozidou, G. Argyropoulos, D. Voutsa, and C. Samara, "Polycyclic aromatic hydrocarbons (PAHs) at traffic and urban background sites of northern Greece: source apportionment of ambient PAH levels and PAH-induced lung cancer risk," Environmental Science and Pollution Research, vol. 23, no. 4, pp. 3556-3568, 2016.

[67] A. J. White, S. L. Teitelbaum, S. D Stellman et al., "Indoor air pollution exposure from use of indoor stoves and fireplaces in association with breast cancer: a case-control study," Environmental Health, vol. 13, p. 108, 2014.

[68] D. L. Diggs, A. C. Huderson, K. L. Harris et al., "Polycyclic aromatic hydrocarbons and digestive tract cancers: a perspective," Journal of Environmental Science and Health, Part C, vol. 29, no. 4, pp. 324-357, 2011.

[69] M. Wiołkomirski and B. Wiołkomirski, "An analysis of soil and plant (Taraxacum officinale) contamination with heavy metals and polycyclic aromatic hydrocarbons (PAHs) in the area of the railway junction Iława Główna, Poland Water," Water, Air, and Soil Pollution, vol. 127, no. 1/4, pp. 339-349, 2001.

[70] M. Nadal, M. Schuhmacher, and J. L. Domingo, "Levels of PAHs in soil and vegetation samples from Tarragona County, Spain," Environmental Pollution, vol. 132, no. 1, pp. 1-11, 2004.

[71] J. J. Nam, B. H. Song, K. C. Eom, S. H. Lee, and A. Smith, "Distribution of polycyclic aromatic hydrocarbons in agricultural soils in South Korea," Chemosphere, vol. 50, pp. 1281-1289, 2003.

[72] D. A. Bright and N. Healey, "Contaminant risks from biosolids land application," Environmental Pollution, vol. 126, no. 1, pp. 39-49, 2003. 